\title{
IMPACT OF EFFECTIVE TIME MANAGEMENT ON ORGANIZATIONAL PERFORMANCE
}

\author{
Abdullahi Babandako Yusuf ${ }^{1}$, Abdulwaheed Adelabu Salihu $^{2}$, Isah Danladi Yahya ${ }^{3}$ and \\ Garba Audu ${ }^{4}$ \\ ${ }^{1,2}$ Department of Business Administration, Faculty of Management and Social Sciences, Ibrahim \\ Badamasi Babangida University, Lapai \\ ${ }^{3}$ Department of Accounting, Faculty of Management and Social Sciences, Ibrahim Badamasi Babangida \\ University, Lapai \\ ${ }^{4}$ Bursary Department, Niger State Polytechnic, Zungeru
}

DOI: 10.46609/IJSSER.2021.v06i07.004 URL: https://doi.org/10.46609/IJSSER.2021.v06i07.004

\begin{abstract}
Time management could be defined as effective use of time for organizational activities in order to achieve the laid down objectives of organizations. The use of time management often enhances organizational performance, and increases organizational output, especially in modern days. This study aims to investigate the impact of time management on organizational performance by measuring the relationship between time management and strategic, customers and leadership approaches. The study is premised on quantitative analysis where multiple regressions is used to analyze the relationship between time management (i.e. dependent variable) and strategic, customer and leadership approaches (i.e. independent variables). The findings of the study reveal that there exist significant relationships between the dependent and independent variables. The study therefore recommends that business organizations should strive to ensure effective and efficient time management in order to enhance organizational performance.
\end{abstract}

Keywords: Time Management, Strategic Approach, Customer Approach, Leadership Approach, Organizational Performance.

\subsection{Introduction/Background of Study}

Time could be described as a period either lengthy or short for which an individual or organization must accomplish a purpose. Time is as old as existence of the world, It can be referred to as a great asset. Time is imperative to all categories of people such as individual, traditional chiefs, corporate body, etc. Every administrator often thinks of how to improve on time management. This shows that time management is key and vital to every individual and 


\section{International Journal of Social Science and Economic Research}

ISSN: $2455-8834$

Volume:06, Issue:07 "July 2021"

organization in today's modern world.

Time is an unessential aid, inelastic, uncommon and disintegrates snappy and once spent, can't be gained back, set away or seemed into for utilize (Kalu, 2012). As showed with the aid of the Oxford advanced Learner's Dictionary time is described as a period either lengthy or quick, among that you satisfy something or something happens whilst administration is portrayed as the show off or aptitude of overseeing people or conditions efficaciously. As per Lakein (1973), time management alludes to the utilization of unique systems, for instance, schedules or intentionally arranging sporting events, or to take an interest in getting ready with the motivation in the back of identifying a way to ace and utilize this kind of method. The estimation of time administration lies in the way that individuals have an immoderate quantity of errands they need to do but insufficient time for the matters that they need to do. Time administration recognizes wishes and needs as some distance as their importance and suits them with time and exceptional belongings Ezine (2008).

Time is an important issue predicted to upgrade different hierarchical exhibitions i.e. the manner time is being overseen in an association will reflect on consideration on its execution either emphatically or contrarily. As indicated with the aid of Joshua (2008), the execution of an affiliation is classified as some distance as the extent of feat of the authoritative objectives and objectives at what financial expenses and productivity. Possible time management is a noteworthy take a look at supervisors in Nigeria are confronting today as they have got a brilliant deal of obligations to perform internal a limited time. Time management methodologies are regularly linked with the suggestion to set individual goals. For singular undertakings or for targets, a significance score is probably built up, due dates might be set, and wishes doled out. Time management carries contributing time to make sense of what one needs out of his regular activities. Effective time administration is the wander of time with the quit intention that becoming consequences are talented from practices inside a selected time variety and it underscores on sufficiency rather than capability. One's potential to choose between the fundamental and the superfluous and be made plans to take after the precisely picked progression is the key determinant of reasonability in time administration. Remembering the remaining goal to direct time, bosses have to be creative and introduce one of kind strategies for conveying yield inner a stipulated time.

Time management according to Wikipedia is the process of planning and exercising conscious control of time spent on specific activities especially to increase effectiveness, efficiency or productivity. Organizational time management is the science of identifying, valuing and reducing time cost wastage within organizations. It identifies, reports and financially values sustainable time, wasted time and effective time within an organization and develops the business case to convert wasted time into productive time through the funding of products, services, projects or 
International Journal of Social Science and Economic Research

ISSN: 2455-8834

Volume:06, Issue:07 "July 2021"

initiatives at a positive return on investment. (www.wikipedia.com)

\subsection{Problem Statement}

Directors do not know about convincing time administration in affiliation, and this is truly affecting the execution of business organizations. It is point of view of this ineffectiveness that the researcher is particularly enthusiastic about contributing the impact of capable time administration on various leveled execution of business associations. Time administration in any business organization is seen as key to gaining ground. Time administration has effect in the administration of any affiliation. This absence of capability prompts inexpediency and viability in the administration of time, particularly when this individual are new to the occupation (Aderami, 2002). Business associations likewise have confounded levels of leadership on which singular representatives need to work so as to accomplish organization's objectives and destinations. This levels of leadership frequently prompts delay in meeting expressed objectives and goals as subordinate need to course their bosses previously choices are taken (Salihu, 2009). Also, numerous business associations need between correspondence pace like radios and updates. This prompts numbness with respect to subordinate keeping in mind the end goal to accomplish hierarchical objectives and objective \& opportune, this absence of correspondence realizes completing day by day exercises in an unscheduled way (Roots et' al, 1999). As a consequence of the above issues talked about, this investigation looks to analyze the viability of the specialist's expectation to help business organizations change administration on authoritative performance.

\subsection{Objectives of the Study}

The main objective of this study is to investigate the impact of effective time management on organizational performance. However, the study is further guided by the following research objectives:

i. To examine the impact of strategic approach to time management on organizational performance in business organizations.

ii. To examine the impact of customer approach to time management on organizational performance in business organizations.

iii. To determine the impact of leadership approach to time management on organizational performance in business organizations.

\subsection{Research Questions}

1. How does strategic approach to time management affect organizational performance in 
business organizations?

2. How does customer approach to time management affect organizational performance in business organizations?

3. How does leadership approach to time management affect organizational performance in business organizations?

\subsection{Formulation of Hypotheses}

1. $\mathrm{H}_{1}$ :-There is significant relationship between strategic approach to time management and organizational performance in business organizations.

2. $\mathrm{H}_{2}$ :-There is significant relationship between customer approach and organizational performance.

3. $\mathrm{H}_{3}$ :-There is significant relationship between leadership approach and organizational performance.

\subsection{Conceptual Framework Model}

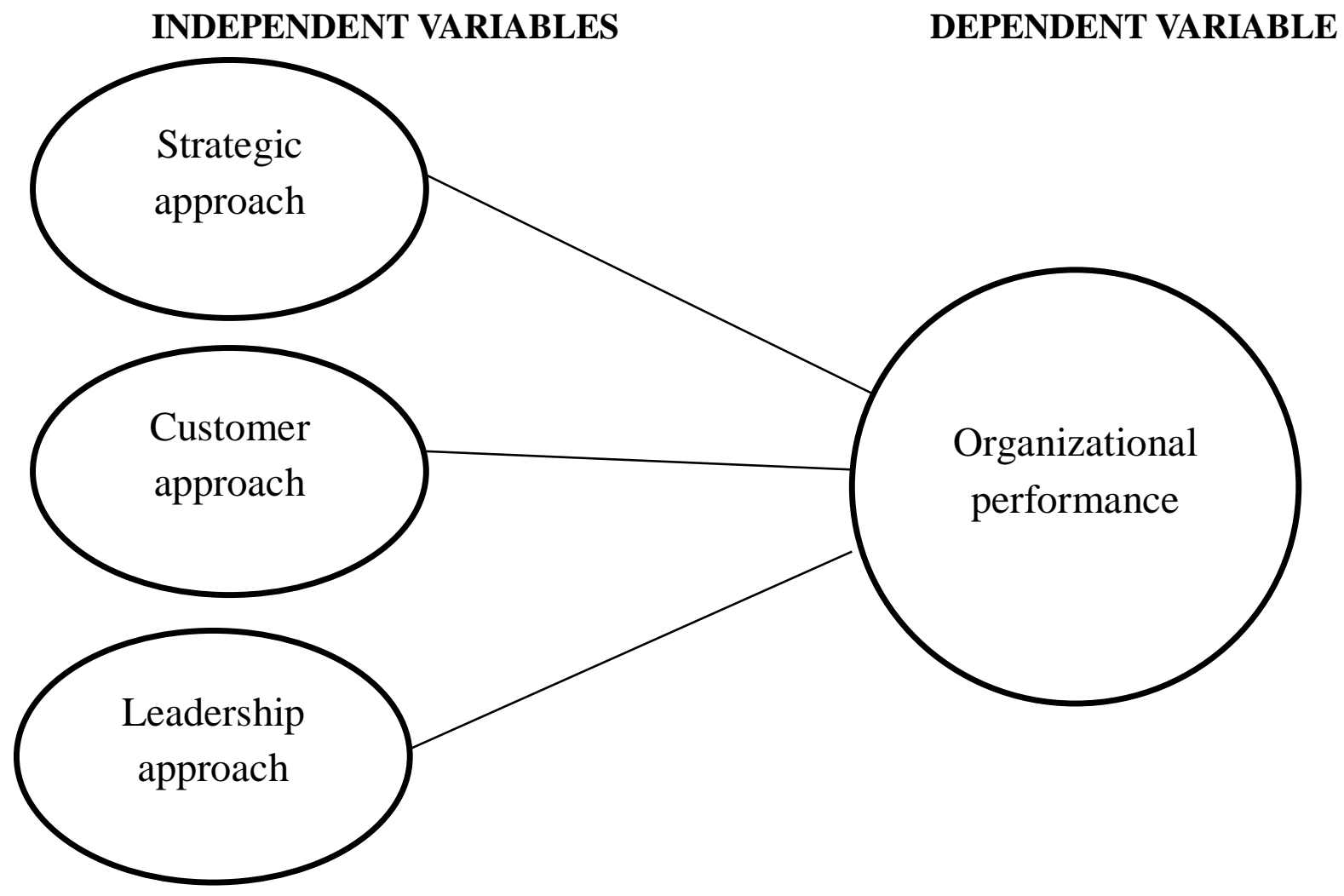


International Journal of Social Science and Economic Research

ISSN: 2455-8834

Volume:06, Issue:07 "July 2021"

\subsection{Literature Review}

\subsection{Concept of Organizational Performance}

During the year 1950's, hierarchical execution was seen as the totality for which business organizations sees as social framework for which they use to satisfied their authoritative goals (Geogopoulos and Tennenbaum, 1957). Associations have an exceptionally noteworthy viewpoint in our everyday exercises; powerful associations unmistakably allude to an essential part of building a general public. Along these lines, various analysts saw associations as a vital device for choosing installments, social and political issues. Execution as a rule was viewed as around then as business related individuals and hierarchical exercises. Later in the 1960's and 1970 's, associations begins growing new ways and examples to hoist their execution rates so execution was characterized as an association's capacity to ponder its prompt surroundings in order to utilize those assets inside (Yuchtman and Seashore, 1967). Execution is viewed as financial and nonmonetary resources which are being utilized to give data on the accomplished goals and results (Lebans and Euske 2006 after Kaplan and Norton 1992).

Whilst all is stated in performed, the idea of authoritative execution depends on contemplate hovered on people and in addition affiliation, and how they relate with both human and nonhuman developments in undertaking a selected purpose (Alchian and Demsetz, 1972; Barney, 2001; Jensen and Meckling, 1976; Simon. 1976). In mild of the reality that the regard made by way of the use of the contributed belongings is identical to or more imperative than the regard predicted via those contributing the focal points, the blessings will preserve being prompted open to the business organizations and the relationship to will preserve existing.

\subsubsection{Theories on Organizational Performance}

In the midst of the year 1900s inside the other bit of the world, a few realists harmonies their musings in various to increase legitimate effectiveness. As predictable with Frederick Taylor inside the US, in the midst of the past due 1800s and mid-1900s, the fundamental typical for each administration is to guarantee best improvement and welfare of its subordinates. A manager should put the commitment concerning productivity rather than on his $\mathrm{kin} /$ subordinates, articulating that it's far the chief's obligation to draft out exact occupations and moreover take a gander at to the convincing achievement of those jobs with needed expense of compensation to fix the determined works of art of the pros (Taylor 1903). In the midst of the mid-1900s, Frank and Lillian Gilbert ascended on the organization scene with a near approach for expanding productivity. Then again, Fayol sees the significance of chief's sufficiency and not what an advisor might need to do to improve the affiliations' execution. Fayol in like manner feels bosses calls for one of a kind ascribes to enhance them advance toward transforming into and more 


\section{International Journal of Social Science and Economic Research}

ISSN: $2455-8834$

Volume:06, Issue:07 "July 2021"

prominent beneficial individuals: physical characteristics, mental qualities, moral highlights, a standard making prepared that contains subjects that don't have a territory exclusively with the confine finished; extraordinary data exceptional to the limitation, be it particular, undertaking, cash related, regulatory, et cetera. on the factor when all is said and performed, amazing and well to uncover change over the battling low-execution associates inside the business undertaking locales they might be unique to the volume measuring execution cites, getting adapted people to finish their occupations and enabling operators to depictions incredibly together, their authorities utilize their abilities, acing and appreciate to make top notch answers for his or her respected clients.

\subsection{Concept of Time Management in Business Organization}

Time is an immaterial and essential asset which is required by using all in everyday sporting events; it is stated that once applied it could by no means be recouped. As indicated by North (2004), time administration is essentially the collection or prioritization of errands or sporting activities by means of dissecting and understanding how an awful lot time each motion will take to be finished, how it will be performed and additionally reducing down time from one of a kind physical games just to get together with the general planned time of the hierarchical sports. Time administration isn't always tied in with doing all physical games at the stipulated time. Its miles tied in with doing every unmarried required movement predicted that could be completed. Time management is the capacity to understand what ought to be finished inside the existence of someone. Time administration essentially implies trying to find better methods and examples to build performance.

As demonstrated by methods for Hisrich and Peters (2002), time is a to a great degree great sum an undertaking man or lady (executive) can't spare it, rent it, and get it. Time organization incorporates contributing time to decide out what one wishes out of his brandishing exercises. Convincing time administration is the endeavor of time with the end goal that immaculate last outcomes are gotten from physical computer games eating up a particular time sum. Time control relies upon the rule that it's far more noteworthy urgent to do the perfect things than to do things appropriate. The ability to pick among the urgent and the irrelevant and be tenacious on the effectively picked gathering is the vital thing determinant of sufficiency in time administration. Time control is a method for directors to collect work execution practicality [Claessens, Roe, Rutte (2009)]. Time control is most likely now not as smooth as what it's far foreseen and expected that would be. Eventually, making assessment inside the bearing wherein they describe time administration. In their exploration, time control: Effectiveness, reason and issues, [Claessens, Roe, Rutte (2009)] have watched that the day and age time administration suggests different issues to various individuals. As constant with Allen (2001), time administration is characterized as practices humans take after to decorate utilization in their possibility. It 


\section{International Journal of Social Science and Economic Research}

ISSN: $2455-8834$

Volume:06, Issue:07 "July 2021"

moreover eludes to requirements and frameworks that people use to determine cognizant options about the wearing exercises that individual their danger.

\subsubsection{Principles of Time Management}

As confirmed by means of journal of coherent studies (2008), the going with are benchmarks for practical time administration.

A. Masterminding: This contains the association of desires and significance of rational methods or dares to be taken to accomplishing identical. In case you are focused round defeating any problems between your capacity and your execution, higher time management must wind up potentially your bearing for residing. There are 3 kinds of recreation plans particularly: Strategic course of movement, direct recreation plan, without a moment's hesitation organizes.

pointers for masterminding encompass: Be specific approximately goals, make locations which can be possible, set sum and time facilities for identical, identification the connection you maintain, do not relate with dream killers, begin near nothing and with what you have got, be satisfied, don't isolate yourself, be flexible, move guides of movement to assess your consequences.

B. Association: organization infers putting all blessings you've got into plan to meet singular goals. The going with are norms for singular relationship at paintings: setting your requirements, time goals are set for wishes, permit time space for the unanticipated, don't set out on multiple foresee without a moment's delay, be a efficient brains, seclude commitments authentically, fill in as showed through your demeanor, do not make fantastic systems, permit time for sit out of rigging minute amongst social occasions and true occupations, awareness on comes approximately not in real existence.

C. Duty: The substance of cutting-edge administration skirts on commitment and duty. It's far regular to find humans passing the greenback for each molecule of disillusionment or irregularity. Winston Churchill stated the fee of significance is obligation. The methods closer to dedication are: Being liable for your character, being chargeable for what you may do, being responsible for what you've gotten, being tried and proper to those who lead you.

D. Duty and integrity: it is one issue to have a intention or dream; it is every other aspect to attain that same goal. Around the entire of specific durations, it is primary for each in a position individual to take supply of true delayed results of his/her physical activities and complexity identical and guides of action.

\subsection{Strategic Approach to Time Management}




\section{International Journal of Social Science and Economic Research}

ISSN: $2455-8834$

Volume:06, Issue:07 "July 2021"

Time management according to Chapman \& Rupured (2017) is a misnomer; as one cannot manage time but manage events in your life or organization in relation to time. They further said, time is like money both valuable and limited hence, it must be protected, used wisely and budgeted. People who practice good time management techniques often find that they are more productive, more energy for things they need to accomplish, less stressed, get more things done, relate more positively to others and feel better about themselves. (Dodd and Sundhein 2005 as contained in Chapman and Rupured 2017).

An affiliation's consistency of key approach chooses its thriving. This consistency can be measured to see how well fitted is the affiliation. World class affiliations tend to set up clear dreams that are supported by versatile and achievable key plans. They moreover have obviously articulated rationalities that set the standards for everyone's lead. In addition, they have pioneers, executives, and laborers who bear on dependably with the key course of action and the business organization`s rationale. Key administration is a strategy of characterizing whole deal targets and goals in perspective of where you have to see your business organization later. For example, you may set essential targets of transforming into a national business, venturing into new markets, differentiating your organization, keeping up cash related benchmarks for commitment and wage administration or isolating yourself from contenders. When you set whole deal crucial destinations, you will sometimes leave without a moment's hesitation openings since they don't support your fundamental targets.

\subsubsection{Key Concepts for Strategic Management and Organizational Performance}

Strategic management is the system in which an affiliation makes and realizes plans that grasp the targets and goals of that affiliation. The methodology of key organization is a reliable one that movements as the various leveled targets and objectives create. Autonomous endeavors partake in vital administration to ensure that they acclimate to design.

Strategic management according to Gartenstein (2016) is an approach to leadership that involves clearly articulating a organization overall vision, mission, objectives and goals to chart progress while performance is measured in reference to these strategic objectives and goals which can be re-evaluated over time as unforeseen circumstances and opportunities present themselves.

\subsubsection{Strategic Goal Setting}

At the focus of the vital administration process is the improvement of desires, an undertaking statement, features and legitimate targets. Legitimate locations, the undertaking declaration, features and targets coordinate the affiliation in its adventure for fundamental open entryways. It's far in like manner via target placing that bosses choose imperative decisions. Strategic goal setting according to Gartenstein (2016) are measurable goals that are consistent with a 
International Journal of Social Science and Economic Research

ISSN: 2455-8834

Volume:06, Issue:07 "July 2021"

company`s vision and mission as they provide concrete milestones for evaluating progress because strategic goals should be based on careful research about opportunities and possibilities and they should be both challenging and achievable. For an example, To grow substantially over the next year- this is not a measurable goal but To grow 20 percent over the next year by opening six new accounts- this is specific and quantifiable.

\subsubsection{Strategic Implementation}

Strategic implementation is the term used to describe the process or activity that ensure the strategic planning is actually executed which means executing what has been planned to do and can be done in six steps of; defining your strategy framework, build your plan, define key performance indicators (KPI), establish your strategy implementation team, report implementation appropriately and link performance to strategy. (www.executestrategy.net)

Technique execution is putting the real technique into schooling to satisfy legitimate destinations. The idea behind this concept is to mixture all the available and key sources required to breathe life into the key direction of action. Institutions recognize techniques thru making spending arrangements, ventures and approaches to address meet cash associated, administration, HR and operational objectives. For the productive execution of a key sport plan, joint attempt amongst management and different staff is completely primary. Method checking a last thought is seeing of the philosophy after its utilization. Strategy checking includes evaluating the technique to pick whether or not it yields the ordinary effects as grasped in the various leveled locations.

\subsection{Consumer Approach to Time Management}

That is the way by means of which an employer treats its customers. Elite associations have a propensity to have clear methods to deal with acquiring new clients, treating current clients, and preserving customers. They additionally assemble the essential foundation and methods to assist their client technique. Associations need to coordinate patron gain into their commercial enterprise objectives and people methodologies need to be fused into representative objectives to guarantee the affiliation achieves their client benefit goals. Representatives just perform at the extent they're overseen and it takes wonderful authority to allow people to comprehend the importance of the purchaser stumble upon. That is the motive it is imperative to have a machine to help make and beef up an administration tradition.

\subsubsection{What is Customer Relationship Management, Or CRM?}

Consumer dating management issues the association among the affiliation and its customers. Clients are the foundation of any affiliation is it an average mission with countless and a multi- 
International Journal of Social Science and Economic Research

ISSN: 2455-8834

Volume:06, Issue:07 "July 2021"

billion turnover, or a sole merchant with an unobtrusive package deal of trendy customers. Client relationship control is the same on a essential level for those two instances - it's far the diploma of CRM that can change actual. CRM makes a specialty of the connection a hit affiliations use three phases to fabricate patron associations: select generally fulfilling dreams among affiliation and clients installation and preserve up customer similarity make fantastic emotions in the association and the customers CRM situations The affiliation and the customers each have units of situations to bear in mind while amassing the connection, for example, wishes and desires of the two facets; affiliations need to make an advantage to continue to exist and create clients require awesome organization, a first-class issue and a commendable esteem correct CRM can affect the 2 courses of action of situations.

\subsubsection{Leadership and Management Style}

Cost primarily based: advances to the self-enthusiasm of adherents to accomplish authoritative objectives and depends at the pioneer's position of expert in the structure. Transformational initiative makes a further stride: it makes a dream for changing the execution of the affiliation and claims to the better ideals and the estimations of the association's relatives to get it going. Individuals are propelled by way of something past their very own precise self intrigue, and they're inspired to give greater exertion than what cost-based administration on my own can accomplish. Transformational administration is visible as an augmentation of price based, instead of another option to it. Beneficial or desirable administration: depends at the man or woman traits or magnetism of the pioneer. Those pioneers are viewed as having a strong vision and feeling of task and stir compelling feelings in adherent.

Power: authority effect is dictated through the source and type of power held by way of the pioneer. These place reviews the speculations of the important thing essayists on manage, which includes: French and Raven, Etzioni's Typology, Fincham's evaluation and Kipnis et al studies.

\subsubsection{Leadership Role in the Organizational Change Process}

These days the intrigue is engaged upon the affects initiative produces for the affiliation. Nowadays supervisors undergo in thoughts initiative as a device with outstanding capability for molding the affiliation, obviously via coordinating the representatives. Their attention actions in the path of the assure of that fashion/display/method of initiative that ought to spark off the wanted consequences in a specific putting as for this example we allude to authoritative trade. (Bejinaru and Băeşu, 2013) nowadays, the pioneer's viability dwells inside the capability to supervise representative resistance and form their conduct closer to using fruitful modifications. Irrespective of the opportunity that this kind of way change executing may be very well portrayed, by way of and with the aid of the use of it turns into a real trouble. Some 


\section{International Journal of Social Science and Economic Research}

ISSN: $2455-8834$

Volume:06, Issue:07 "July 2021"

modifications, as incremental adjustments are less difficult stated and achieved as those are constantly and casually linked. In time people get used to this form of modifications and become a popular, never like radical adjustments. Then again, radical modifications are considerably more hard to be said and protection is more grounded this is the thought process are basic legitimate activity capacities. Radical alterations require a chose level of affirmation protecting in considerations the stop expect to make status to surrender antique assortments of working for new ones. (Reardon 1998) In late written work, experts have widened the examination and talks roughly the pioneers' detail inside the relationship to different internal and out troubles similar to the impacts of numerous initiative styles upon the manner inside the path of actualizing authoritative trade. Different pioneers ought to have numerous perspectives approximately the development and could technique their element in encouraging execution in diverse strategies. The views, styles, and practices of man or woman pioneers must be comprehended, and framework bolster systems must recollect those distinctions. As an example Higgs and Rowland (2000, 2001) have investigated upon the connection amongst some kinds of initiative and hierarchical change. As in keeping with their consequences we show 5 big competency areas of authority diagnosed with fruitful utilization of authoritative alternate: developing the case for alternate building mindfulness among representatives regarding the technique of development and it's want. Drawing in unique getting individuals included and resolved to hold going for walks along the exchange gadget. Empowering and making ability manual people to locate their own one of a kind thought for brandishing out change.

There are some radical students who battle that the utilization of trade is the essential piece of a pioneer and the total else is assistant. Yukl thinks around that as a pioneer is genuinely convincing on the off peril that he or she wins to modify the relationship to a changing situation through predictable restoration. He emphasizes on know-how the capacities in the again of impenetrability to change, the back to back levels inside the change technique, and brilliant frameworks to exchange will beautiful enhance its likelihood of productive change execution. (Yukl, G. 1998).

\subsubsection{Leadership Traits}

For the main portion of the 20th century it became general that it's far doable to understand and confine a restricted arrangement of attributes, which could be applied while selecting and raising humans to management positions. This inquiry became firmly impacted by means of the enormous guy speculation that concentrated on how (principally male) figures performed and stored up locations of impact. In a large survey of traits contemplates, Stogdill (1974) located some traits that appeared more frequently than others. comparable traits, be that as it can, has no longer been identified in one of a kind examinations (e.g. bird, 1940; Stewart, 1963) and with the rundown developing ever longer it has now been broadly stated that no such whole association of 
International Journal of Social Science and Economic Research

ISSN: 2455-8834

Volume:06, Issue:07 "July 2021"

characteristics will ever be prominent. Its miles clear, but, that none of these are good enough in themselves to serve reasons for the advancement of wide-spread pioneers.

Stogdill (1974) featured a part of the attributes to contain the followings: strong power for responsibility, deal with completing the assignment, strength and perseverance in quest for targets, wander similarity and creativity in vital thinking, drive to practice activity in social settings, mythical being certainty, feeling of individual character, capacity to impact the conduct of others, ability to structure social framework to the reason close by.

\subsection{Methodology}

\subsection{Research Design}

In venture with Okezie (2002), look at amusement design is depicted as a substantial heading of development, drawing or plan showing the photo and working or workings of the examination machine sooner than it's far had with. So in like manner, Asika (1991) sees it as the discovering of exam went for seeing components and their relationship with each other. This exam influences utilization of the utilization of legitimate investigations to plot. The Layout is away to take a gander at the relationship among time association and imaginative execution.

\subsection{Population and Sample of the Study}

A populace is comprised of every single feasible issue, subjects or perceptions figuring out with a particular marvel vital to the professional (Asika, 1991). There are a hundred staffs in business and popular coverage plc Minna, Niger state. Finally, the number of inhabitants within the exam is made from the whole staff of commercial and preferred insurance percent, Minna, even as the instance measure attracted is constrained to 80 respondents as indicated through Yaro Yamani's recipe out of an anticipated populace of 100 laborers constituting of the 2 representatives and administration of industrial and fashionable insurance p.c.

\subsection{Sampling Framework}

This sample size is drawn with the useful resource of Yaro Yamani's formulation as expressed beneath:

$\frac{N}{1+N(e)^{2}}$

Where:

$\mathrm{n}=$ Sample Size 
$\mathrm{N}=$ Population Size

$\mathrm{e}=$ Level of Significance (error)

$1=$ A Constant Number

For the purpose of this study, our level of significance $(e)=5 \%$ or 0.05 that is $95 \%$ confidence limit.

$\mathrm{N}=100$

(e) $=0.05$ or $5 \%$

Substituting the above values into the formula, we have that:

$$
\begin{gathered}
n=\frac{100}{1+100(0.05)^{2}} \\
n=\frac{100}{1+100(0.0025)} \\
n=\frac{100}{1+0.25} \\
n=\frac{100}{1.25} \\
n=80
\end{gathered}
$$

Therefore, the pattern size for this take a look at was 80 respondents in industrial and preferred coverage that is representing a extra percent of the population length.

\subsubsection{Source of Instrument of Data Collection}

Collection of statistics can be described to be a technique used as a chunk of social event correct studies statistics. This technique generally stipulates how statistics is amassed and there are six vital and essential systems for social event information which can be in keeping with the accompanying; Questionnaires, consciousness get togethers, tests, popularity, gatherings and 
International Journal of Social Science and Economic Research

ISSN: 2455-8834

Volume:06, Issue:07 "July 2021"

discretionary records. (Teddlie and Tashakkori, 2008). This investigation became broaden best as for surveys. Overviews can be portrayed because the course in the direction of acquiring more facts via the medium of making request whether person or widespread less using individual or at ease joint attempt. The critical use of overviews is getting more records approximately the everyday wander and it may be used for various motives in an examination do not forget. in keeping with Wilson and Maclean (1994), survey gives researcher more getting to know into social occasion statistics from an significant degree of people and moreover essentially accommodating in carrying out facts which can be may be all round illuminated. Survey in like manner has some burden which are in keeping with the accompanying; there's the piece of time conditions on account that they consumed an brilliant degree of time to completely deliver an actual final results, the problem of converting is moreover being alluded to in mild of the fact that multiple data may additionally dismiss to offer accurate solutions inside the piece of restrained reaction so along these traces they ought to be refined (Cohen et at, 2000). research are useful within the piece of taking a gander at happens collectively, clean to renowned and moreover they supply a practical photograph of what has been asked approximately and besides the final results. Recipients of examine are limited to give genuine and truthful solutions in mild of the fact that there's no man or woman joint effort with the researcher, for that reason they have got the unreasonable choice to give accurate reaction.

\subsection{Source of Data Collection}

Facts might be gathered thru important assets. The critical wellspring of data applied as a part of this exploration turned into the survey. This protected an arrangement of inquiries where respondents are made a request to choose selections that fulfill their exams. Moreover, the close by survey turned into applied as a part of the research.

\subsection{Data Analysis Techniques}

This investigation will utilize the usage of both illustrative and inferential insights to have a look at the data gathered. The method so as to be applied for exam of records thru poll agency to the respondent blanketed the usage of a authentic approach. Take a look at relapse exam may be performed with the guide of measurable package deal for sociologies (SPSS) to break down the records series.

\subsection{Analysis of Data}


International Journal of Social Science and Economic Research

ISSN: 2455-8834

Volume:06, Issue:07 "July 2021"

Table: 26

Variables Entered/Removed

\begin{tabular}{|l|l|l|l|}
\hline $\begin{array}{l}\text { Mode } \\
1\end{array}$ & Variables Entered & $\begin{array}{l}\text { Variables } \\
\text { Removed }\end{array}$ & Method \\
\hline 1 & $\begin{array}{l}\text { Strategic approach, customer } \\
\text { approach, leadership approach }\end{array}$ &. & Enter \\
\hline
\end{tabular}

a. Dependent Variable: Organizational performance

b. All requested variables entered.

The table above shows the total numbers of independent variables entered and removed when analyzing data on SPSS. Strategic approach, customer approach and leadership approach were transformed to represent a single independent variable (b) in order to compare the relationship of the dependent variable and independent variables.

Table: 27

\section{Model Summary}

\begin{tabular}{|l|l|l|l|l|}
\hline $\begin{array}{l}\text { Mode } \\
1\end{array}$ & $\mathrm{R}$ & $\mathrm{R}$ Square & $\begin{array}{l}\text { Adjusted } \\
\text { Square }\end{array}$ & $\begin{array}{l}\text { Std. Error of } \\
\text { the Estimate }\end{array}$ \\
\hline 1 & $.162^{\mathrm{a}}$ & .026 & -.012 & 1.07788 \\
\hline
\end{tabular}

a. Predictors: (Constant), Strategic approach, customer approach, leadership approach.

The table above shows the coefficient of correlation value $\mathrm{R}$ as 0.162 . This figure indicates that there is no relationship between the dependent variable (Organizational Performance) and independent variables (Strategic approach, customer approach, leadership approach).

$\mathrm{R}$-square is given as 0.026 . This value indicates that Organizational performance explained about 
International Journal of Social Science and Economic Research

ISSN: 2455-8834

Volume:06, Issue:07 "July 2021"

$26 \%$ of the variance while the remaining $74 \%$ is explained by Strategic approach, customer approach and leadership approach.

Also, from the table the adjusted R-square is 0.012. The lower the R-square the higher the standard deviation (such as standard of error) of the residual as shown in the table (1.07788.).

Table: 28

ANOVA $^{\mathrm{a}}$

\begin{tabular}{|ll|l|l|l|l|l|}
\hline Model & $\begin{array}{l}\text { Sum of } \\
\text { Squares }\end{array}$ & Df & $\begin{array}{l}\text { Mean } \\
\text { Square }\end{array}$ & F & Sig. \\
\hline \multirow{4}{*}{$1 \quad$ Regression } & 2.388 & 3 & .796 & .685 & $.564^{\mathrm{b}}$ \\
& Residual & 88.299 & 76 & 1.162 & & \\
& Total & 90.688 & 79 & & & \\
\hline
\end{tabular}

a. Dependent Variable: Organizational performance

a. b. Predictors: (Constant), Strategic approach, customer approach, leadership approach.

b. The table above shows the mean square of regression score as 0.796 and the residual value as 1.162. The table also depicts the significant level of the three independent variables i.e. (Strategic approach, customer approach and leadership approach) on the table which is greater than 0.05 which means that there is significant relationship between the dependent variable (Organizational performance) and independent variables (Strategic approach, customer approach and leadership approach) 
International Journal of Social Science and Economic Research

ISSN: 2455-8834

Volume:06, Issue:07 "July 2021"

Table: 29

\section{Coefficients $^{\mathrm{a}}$}

\begin{tabular}{|c|c|c|c|c|c|}
\hline \multirow[t]{2}{*}{ Model } & \multicolumn{2}{|c|}{$\begin{array}{l}\text { Unstandardized } \\
\text { Coefficients }\end{array}$} & \multirow{2}{*}{\begin{tabular}{|l}
$\begin{array}{l}\text { Standardized } \\
\text { Coefficients }\end{array}$ \\
Beta
\end{tabular}} & \multirow[t]{2}{*}{$\mathrm{T}$} & \multirow[t]{2}{*}{ Sig. } \\
\hline & B & Std. Error & & & \\
\hline (Constant) & 2.190 & .417 & & 5.256 & .000 \\
\hline $\begin{array}{l}\text { Strategic } \\
\text { approach, }\end{array}$ & -.079 & .135 & -.069 & -.582 & .562 \\
\hline $\begin{array}{l}\text { Customer } \\
\text { approach, }\end{array}$ & -.137 & .114 & -.137 & -1.202 & 233 \\
\hline $\begin{array}{l}\text { Leadership } \\
\text { approach }\end{array}$ & .201 & 261 & .091 & .771 & .004 \\
\hline
\end{tabular}

a. Dependent Variable: Organizational performance

The above table shows the coefficient level of the independent variable. The significance level of the three independent variables is $0.562,0.233$ and 0.004 . Since the first value is more than 0.05 it shows that the value of the variable implies negative while the last two which are lower than 0.05 imply positive.

\subsection{Test of Hypothesis}

\section{Test of Hypothesis One}

\section{Interpretation}

The correlation value has shown that the level of significant in the row labeled Sig. in strategic approach is 0.562 which is greater than the alpha value of 0.05 ; it means the result is not significant.

\section{Hypotheses One}

$\mathbf{H}_{1}$ : -There is significant relationship between strategic approach to time management and organizational performance in business organizations. 
Ho1: - There is no significant relationship between strategic approach to time management and organizational performance in business organizations.

\section{Decision Rule}

Since Psig (0.562)>Pvalue (0.05) hence, the alternate hypothesis $\left(\mathbf{H}_{\mathbf{1}}\right)$ is rejected while the null (Ho1) is accepted. This means that there is no significant relationship between strategic approach to time management and organizational performance in business organizations.

\section{Test of Hypothesis Two}

\section{Interpretation}

The correlation value has shown that the level of significant in the row labeled Sig. in customer approach is 0.233 which is greater than the alpha value of 0.05 ; it means the result is not significant.

\section{Hypothesis Two}

H2: - There is significant relationship between customer approach and organizational performance.

Ho2: - There is no significant relationship between customer approach and organizational performance.

\section{Decision Rule}

Since Psig. (0.233)>Pvalue (0.05) hence, the alternate hypothesis $\left(\mathbf{H}_{2}\right)$ is rejected while the null $\left(\mathbf{H o}_{2}\right)$ is accepted. This means that there is no significant relationship between customer approach and organizational performance.

\section{Test of Hypotheses Three}

\section{Interpretation}

The correlation value has shown that the level of significant in the row labeled Sig. in leadership approach is 0.004 which is less than the alpha value of 0.05 ; it means the result is significant.

\section{Hypothesis Three}

H3: - There is significant relationship between leadership approach and organizational performance. 
International Journal of Social Science and Economic Research

ISSN: 2455-8834

Volume:06, Issue:07 "July 2021"

Ho3: - There is no significant relationship between leadership approach and organizational performance.

\section{Decision Rule}

Since Psig. $(0.004)<$ Pvalue (0.05) hence, the alternate hypothesis $\left(\mathbf{H}_{3}\right)$ is accepted while null (Ho3) is rejected. This means that there is significant relationship between leadership approach and organizational performance.

\subsection{Discussion of Findings}

The current study was conducted to investigating the impact of effective time management on organizational performance, industrial and general insurance Plc as case study. The research model variables used was strategic approach, customer approach and leadership approach. The finding shows that the strategic approach has negative impact on organizational performance. It was observed in this study that there exists no significant relationship between strategic approaches to organizational performance. It was also discovered from the findings that customer approach has significant relationship with organizational performance of Industrial and General Insurance Plc. And lastly for leadership approach, it was observed that there is a significance relationship with organizational performance.

To supplement this exam, the change represents considerable authority in the disclosures of the three goals of the exam. That is to discover to what degree the exam changed into made conceivable with everything taken into account. Before drive talk at the objectives of the exam, the exam appeared to be in vogue revelations of the entire staff and their idea on the goal of association execution the productive time company which are viewed as effective through respondents. The standard objective of this examination is to hinder down the impact of pivotal strategy to time organization on various leveled execution in business venture affiliations. The second attention to the examination is to analyze the impact of customer method to time business endeavor on various leveled execution in big business affiliations and the 0.33 is to pick the impact of leisure activity way to deal with time association on conclusive execution in business undertaking affiliations. The case is created from entire staff of business and well known scope percent, Minna in their conviction on affiliation execution. A whole of eighty respondents had answered to inquire about issued. Quantifiable bundle bargain for Social science (SPSS) variant 17 wound up noticeably used to part the realities amassed. Distributive actualities examination strategy, for instance, rehash and charge has been utilized to portray estimation and appraisal of the respondents' level of complete execution to the connection.

\subsection{Summary}




\section{International Journal of Social Science and Economic Research}

ISSN: $2455-8834$

Volume:06, Issue:07 "July 2021"

The great estimated inspiration in the back of this examination moved toward becoming to investigate the effect of convincing time administration on definitive execution. Examination reveals that basic system factor of time administration definitely impacts various leveled execution; moreover the client approach part of time administration has vital effect on legitimate execution. At protracted extreme the administration technique factor of time organization eminently influences progressive execution.

\subsection{Conclusion}

Effective time corporation is a reaction for modern ampleness and now not a phony remedy. Convincing Time Corporation will improve body of workers effectiveness, make arranging of occupations less inquiring for, affect personnel to perform errands at their maximum dazzling bent to level, assisting staff to kind out and fulfill simple undertaking, recording and coordinating the relationship toward finishing its set goals. Being powerful in appreciate of using time does immoderate manner a settled state of good sized well worth. it can be acquired thru getting to know and making through enduring working towards and experience. Time will simply work if the character is given definitely to it along those strains ousting any shred of inquiries. The most critical and dire settling is warranty, this is part into edges. Immediately, one desires to wellknown and feature the whole sureness that studying is viable and moreover the exchange of the capacities is possible as properly. Plus, the time company frameworks ought to be located stock in mild of the way that if now not, it is to a splendid diploma a long way-fetched it could work. If the two viewpoints may be gifted, by using then the level of ampleness can be large. The exam observed that larger piece of the affiliation body of workers are lively, single, appreciably skilled and has been running for a concise time span ( five years), this suggests the affiliation is rebranding and heaps of sporting activities has been taken into consideration. Around the cease, information collected and tried exhibited an association among the two elements in the examination work. Along these traces, obviously the realistic time company for tip pinnacle in association cannot be overlooked in mild of the truth that it could achieve an over the top diminishing in affiliation execution. In that restrict, affiliation should take powerful time business enterprise with all genuineness for excessive association execution.

\subsection{Recommendations}

From discoveries, virtually possible time management is an apparatus for association execution. consequently, it's far prescribed that association must hold completely to possible time administration preserving in thoughts the end aim to present best administrations to their customers. The accompanying time administration recommendations are likewise advised:

- listing the principle time squandering instances and make clear why those instances emerge. To 


\section{International Journal of Social Science and Economic Research}

ISSN: $2455-8834$

Volume:06, Issue:07 "July 2021"

avoid endeavoring excessively venture; make certain you rent the ideal errand to the best character. To make utilization of innovation enables and make use of the most suitable kind of innovation to your motivation.

- At the same time as voyaging you can speak about with associates to spare time of assembling a conference. each powerful individual have to deal with time deliberately, due to the fact nothing impacts the number one concern of an affiliation greater than time adequacy of its family members (a few authentic do nothing actual approximately it).

With a particular cease intention to make a duration cognizant association that one must turn out to be extra time powerful, and that the affiliation itself streamlines it method. The advantages an association will harvest in destiny depend on what the corporation does with their hazard at this factor. The important component of time is occasion. What's more, key to effective time administration is event control. This is to country that an association cannot time, but the affiliation can control what they do with time.

Watching for that representatives in an affiliation realize how to oversee time in light of the truth that the great management is aware of is awful. Laying accentuation on the importance of good time administration at steady gatherings is an brilliant technique for making sure that every one of the representatives are at the complete mindful of it.

\section{REFERENCES}

Afolabi G.K \& Okezie G.N (2005), Project Writing and Supervision. Ibadan: Gold Field Printers.

American Management Association Journal (2007), pp 8-19 Effective time management for high performance in organizations. Journal of Nigerian institute Of management, vol, 44 No. 3 pp. 21-26.

Asika, N. (2000) Research Methodology in the Behavioral Sciences Lagos. Longman Press.

Ayegh, N.A (2005) Value for Money Audit: A Veritable Tool to curtail Expenditure. In Accountancy News (January-March). Jos: Association of National Accountants of Nigeria.

Bass, B. M. (1998) Transformational leadership: Industrial, military, and educational impact. Mahwah. NJ: Erlbaum.

Bass, B. M., \&Avolio, B. J. (1990) Training and development of transformational leadership for individual, team, and organizational development. In R. W. Woodman \& W.A. Passmore (Eds.), Research in organizational change and development. Greenwich, CT: JAI Press. 
International Journal of Social Science and Economic Research

ISSN: 2455-8834

Volume:06, Issue:07 "July 2021"

Eruteyan, J.O (2008) Effective time management for high performance in organizations, Journal of Nigerian Institute of Management, vol, 44 No 3 pp.21- 26.

Gartenslem, D. (2016) Key Concepts of Strategic Management and Organizational goals. www.azcentral.com.

Ghauri P \& Gronhaug K, 2005. Research Methods in business studies: A practical Guide (Ebook). New York. Financial Times Prentices.

Higgs, M and Rowland, D. (2005) All Changes Great and Small: Exploring Approaches to Change and its Leadership. Journal of Change Management, vol. 5, No. 2, pp. 121-151, June 2005.

Higgs, M. \& Rowland, D. (2000) Building leadership change capability, Henley Working Paper Series, HWP 2000/04.

Hirschman, E, (1987) Theoretical perspectives of time use: Implications for consumer behavior Research, Research in consumer behavior, vol,2 pp. 55-81.

Hisrich \& Peters (2002) Effective time management for high performance in organizations, Journal of Nigerian Institute of Management, vol, 44 No 3 pp. 21- 26.

Lakein, A (1973) How to get control of your time \& your life: New American Library, New York.

Lewis, D \&Weigert, D (1981) The structure and meanings of social time, Social forces, vol, 60 pp. 452-457 Limited.

Macan, T (1994) time management: test of a process mode, Journal of applied psychology, vol, 79 pp. 381-391.

Macan, T (1996) Time management training: effective on time behaviors, attitudes \& job performance, , the journal of psychology, vol, 130 No 3pp.229-236.

Macmillan English Dictionary for advanced learners (2007), Macmillan publishers limited, Malaysia.

Marschan R \& Welch C 2004. Handbook of qualitative research methods for international Business (EBook) Edward Elgar Publishing Limited UK, Available in Google books.

North: Y (2004) God's Clock maker; Richard of Wallingford \& the invention of time Oxbow Books. 
International Journal of Social Science and Economic Research

ISSN: 2455-8834

Volume:06, Issue:07 "July 2021"

Ojo L.B \&Olaniyan, D.A (2008) Effective time management in organization Panacea or Placebo, European Journal of Scientific Research, vol, 24 No 1 pp.127-133.

Sue, W. C \& Rupured, M. (2017) Ten Strategies for Better Time Management; The University of Georgia Cooperative Extension Colleges of Agriculture and Environmental Studies. Georgia, Atlanta USA.

wWw.wikipedia.com.

www.executestrategy.net.

Yukl, G. (1998) Leadership in Organizations, Prentice-Hall, Upper Saddle River, New Jersey, 4th Edition. 